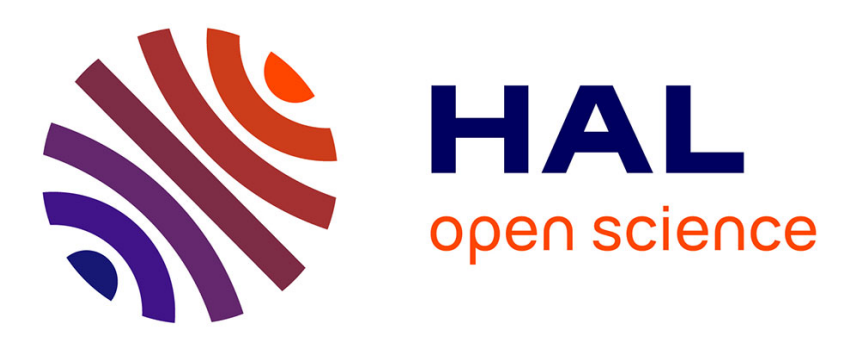

\title{
Carbon stable isotope analysis of methylmercury toxin in biological materials by gas chromatography isotope ratio mass spectrometry
}

\author{
Jeremy Masbou, David E Point, Gaël Guillou, Jeroen E Sonke, Benoit
}

Lebreton, Pierre E Richard

\section{To cite this version:}

Jeremy Masbou, David E Point, Gaël Guillou, Jeroen E Sonke, Benoit Lebreton, et al.. Carbon stable isotope analysis of methylmercury toxin in biological materials by gas chromatography isotope ratio mass spectrometry. Analytical Chemistry, 2015, 87, pp.11732-11738. 10.1021/acs.analchem.5b02918 . hal-01450034

\section{HAL Id: hal-01450034 \\ https://hal.science/hal-01450034}

Submitted on 30 Jan 2017

HAL is a multi-disciplinary open access archive for the deposit and dissemination of scientific research documents, whether they are published or not. The documents may come from teaching and research institutions in France or abroad, or from public or private research centers.
L'archive ouverte pluridisciplinaire HAL, est destinée au dépôt et à la diffusion de documents scientifiques de niveau recherche, publiés ou non, émanant des établissements d'enseignement et de recherche français ou étrangers, des laboratoires publics ou privés. 


\section{Carbon stable isotope analy- sis of methylmercury toxin in biological materials by gas chromatography isotope ra- tio mass spectrometry}

JeremyMasbou ${ }^{\dagger+}$, David Point ${ }^{*},+$, GaëlGuilIou $^{\ddagger \ddagger}$, Jeroen E. Sonke ${ }^{\dagger}$, BenoitLebreton ${ }^{\ddagger \ddagger}$, Pierre Richard ${ }^{\ddagger}$

\begin{abstract}
${ }^{\dagger}$ Observatoire Midi-Pyrénées, Géosciences Environnement Toulouse, UMR CNRS 5563/IRD

234/Université Paul Sabatier Toulouse 3, 14 avenue Edouard Belin, 31400 Toulouse, France

FUMR Littoral, Environnement et Sociétés (LIENSs), UMR 7266 CNRS-Université de La Rochelle, Institut du Littoral et de l'Environnement, 2 rue Olympe de Gouges, 17000 La Rochelle, France.

Methylmercury, carbon, compound specific stable isotopic analysis, GC-C-IRMS, biological materials, standard reference materials, marine biogeochemistry
\end{abstract}

ABSTRACT:A critical component of the biogeochemical cycle of mercury $(\mathrm{Hg})$ is the transformation of inorganic $\mathrm{Hg}$ into neurotoxic monomethylmercury $\left(\mathrm{CH}_{3} \mathrm{Hg}\right)$. Humans are exposed to $\mathrm{CH}_{3} \mathrm{Hg}$ by consuming marine fish, yet the origin of $\mathrm{CH}_{3} \mathrm{Hg}$ in fish is a topic of debate. The carbon stable isotopic composition $\left(\delta^{13} \mathrm{C}\right)$ embedded in the methyl group of $\mathrm{CH}_{3} \mathrm{Hg}$ remains unexplored. This new isotopic information at the molecular level is thought to represent a new proxy to trace the carbon source at the origin of $\mathrm{CH}_{3} \mathrm{Hg}$. Here, we present a compound specific stable isotope analysis (CSIA) technique for the determination of the $\delta^{13} \mathrm{C}$ value of $\mathrm{CH}_{3} \mathrm{Hg}$ in biological samplesby gas chromatography combustion isotope ratio mass spectrometry analysis (GC-C-IRMS). The method consisted first of calibrating $\mathrm{aCH}_{3} \mathrm{Hg}$ standard solutionfor $\delta^{13} \mathrm{C}$ CSIA. This was achieved by comparing three independent approaches consisting of the derivatization and halogenation of the $\mathrm{CH}_{3} \mathrm{Hg}$ standard solution. The determination of $\delta^{13} \mathrm{C}_{\mathrm{CH} 3 \mathrm{Hg}}$ values on natural biological samples was performed by combining a $\mathrm{CH}_{3} \mathrm{Hg}$ selective extraction, purification and halogenation followed by GC-C-IRMS analysis. Reference $\delta^{13} \mathrm{C}$ values were established for a tuna fish certified material (ERMCE464) originating from the Adriatic Sea $\left(\delta^{13} \mathrm{C}_{\mathrm{CH}} \mathrm{Hg}=-\right.$ $22.1 \pm 1.5 \%, \pm 2 S D$ ). This value is similar to the $\delta^{13} \mathrm{C}$ value of marine algal derived particulate organic carbon $\left(\delta^{13} \mathrm{CPOC}=-21 \%\right)$.

\section{Introduction}

The toxicity of mercury $(\mathrm{Hg})$ is directly related to its chemical forms. Biogenic organometallic compounds that are naturally produced in aquatic ecosystems such as methylmercury $\left(\mathrm{CH}_{3} \mathrm{Hg}\right)$ are known to be potent neurotoxins and to bioaccumulate along aquatic food chains $^{2}$. Marine sea food consumption represents the main source of human $\mathrm{CH}_{3} \mathrm{Hg}$ exposure ${ }^{3}$, with socioeconomical costs estimated to several billions of dollars/year worldwide ${ }^{4}$.

Methylmercury is thought to be primarily produced by sulfate reducing bacteria ${ }^{5-7}$, yetother anaerobic microorganisms hosting specific methylation genes ${ }^{8}$, and possibly complementary abiotic pathways may also be at play ${ }^{10}$. The rapid assimilation of $\mathrm{CH}_{3} \mathrm{Hg}$ by primary producers (phytoplankton) ${ }^{11}$ and further biomagnification along aquatic foodwebs is well documented ${ }^{12,13}$. Yet, understanding where, how and when $\mathrm{CH}_{3} \mathrm{Hg}$ is produced at the base of aquatic ecosystems remains a subject of ongoing debate. Lake, coastal and marine sediments have long been identified as important sites for microbial $\mathrm{Hg}$ methylation ${ }^{14-16}$. However, relating elevated open ocean fish $\mathrm{CH}_{3} \mathrm{Hg}$ levels to sediment $\mathrm{CH}_{3} \mathrm{Hg}$ sources is unrealistic ${ }^{17}$. Recent marine studies on $\mathrm{CH}_{3} \mathrm{Hg}$ provide mounting evidence for in situ water column production of $\mathrm{CH}_{3} \mathrm{Hg}^{18-21}$.

Answering fundamental questions on the origin of $\mathrm{CH}_{3} \mathrm{Hg}$ is directly driven by the state of $\mathrm{Hg}$ metrology. Traditional $\mathrm{Hg}$ speciation techniques mostly involve a gas chromatographic (GC) separation coupled to a sensitive $\mathrm{Hg}$ detector such Atomic Fluorescence Spectroscopy (AFS) or Inductively Coupled Plasma Mass Spectrometry (ICP-MS) ${ }^{22}$. These techniques have permitted measurement of $\mathrm{CH}_{3} \mathrm{Hg}$ concentrations in a wide range of key compartments of the biogeosphere (biota, oceans, atmosphere, food chain, sediments, soils). The increasing use of mass spectrometry in $\mathrm{Hg}$ research has allowed researchers to use enriched $\mathrm{Hg}$ stable isotopes in laboratory or field tracer studies to quantity the kinetics of $\mathrm{Hg}$ transformations and/or its transfer among compartments ${ }^{23,24}$. More recently, the analysis of the natural stable isotopic variations of $\mathrm{Hg}$ by cold vapor multicollector inductively coupled plasma mass spectrometry (CV-MC-ICPMS) in biogeomatrices provided a new angle on tracking $\mathrm{Hg}$ sources and dynamics ${ }^{25,26}$. Until now, most measurements of $\mathrm{Hg}$ stable isotope compositions in environmental samples have been performed on total $\mathrm{Hg}$ concentrations. Recent analytical developments in the field of $\mathrm{Hg}$ compound specific stable isotopic analysis ( $\mathrm{Hg}$-CSIA) allow to trace $\mathrm{Hg}$ dynamics at the molecular level ${ }^{27,28}$. No attention has been devoted, however, to the isotopic variations of the carbon atom at the molecular level in the $\mathrm{CH}_{3} \mathrm{Hg}$ compound. The isotopic composition of this component may be used to better understand the role of organic matter and to trace the carbon sources at the origin of the formation of $\mathrm{CH}_{3} \mathrm{Hg}$.

In this study, we developed a new analytical approach to investigate the unexplored carbon isotope side of the $\mathrm{CH}_{3} \mathrm{Hg}$ toxin cycle. Recent analytical developments 
permit the CSIA of light elements $(\mathrm{C}, \mathrm{H}, \mathrm{N}, \mathrm{O})$ by gas chromatography-combustion-isotope ratio mass spectrometry (GC-C-IRMS). Examples are the determination of the $\delta^{13} \mathrm{C}$ values of individual organic compounds: amino acids ${ }^{29}$, fatty acids ${ }^{30}$, greenhouse gases ${ }^{31}$, organic anthropogenic contaminants ${ }^{32}$, but also biogenic organometallic arsenic compounds ${ }^{33}$. Here, we present the first method for the determination of $\delta^{13} \mathrm{C}$ values of $\mathrm{CH}_{3} \mathrm{Hg}$ using CSIA $\left(\delta^{13} \mathrm{C}_{\mathrm{CH}} \mathrm{Hg}\right.$ ) in biological materials.

\section{Experimental Section}

\section{Reagents, standards and reference materials}

Millipore $18.6 \mathrm{M} \Omega . \mathrm{cm}^{-1}$ ultrapure water, bidistilled nitric and hydrochloric acids were used for preparation of all solutions throughout this study. Sodium bromide $(\mathrm{NaBr}$, Ultra grade $99.5 \%$ ), potassium iodide (KI, ACS grade $\geq 99 \%$, anhydrous cupric sulphate $\left(\mathrm{CuSO}_{4}\right.$, reagent grade $99 \%+)$, sodium thiosulfate $\left(\mathrm{Na}_{2} \mathrm{~S}_{2} \mathrm{O}_{3}\right.$, reagent grade $98 \%)$, sodium acetate $\left(\mathrm{CH}_{3} \mathrm{COONa}\right.$, ACS grade $99 \%+)$, methanol $\left(\mathrm{CH}_{3} \mathrm{OH}\right.$, anhydrous $\left.99.8 \%\right)$, toluene (anhydrous $99.8 \%$ ), hexane (anhydrous $\geq 95 \%$ ), sulphuric acid $\left(\mathrm{H}_{2} \mathrm{SO}_{4}, \mathrm{ACS}\right.$ grade $\left.95-98 \%\right)$ and anhydrous $99.8 \%$ grade iso-octane were purchased from Sigma Aldrich (Milwaukee, WI, USA). Ultra grade glacial acetic acid $\left(\mathrm{CH}_{3} \mathrm{COOH}, 99 \%\right)$ was purchased from Avantor ${ }^{\mathrm{TM}}$ (Netherlands). Sodium tetrapropylborate $\left(\mathrm{NaB}\left(\mathrm{C}_{3} \mathrm{H}_{7}\right)_{4}\right)$ and sodium tetraethylborate $\left(\mathrm{NaB}\left(\mathrm{C}_{2} \mathrm{H}_{5}\right)_{4}\right)$ obtained fromMerseburgerSpezialchemikalien (Germany) were prepared daily and stored at $-18^{\circ} \mathrm{C}$ until use. All polypropylene or Teflon labware used in this study were acid cleaned. Glass labwarewas cleaned by pyrolysis before use.

The primary $\mathrm{CH}_{3} \mathrm{Hg}$ reference standard stock solution used in this study was prepared from a methylmercury chloride salt (Sigma Aldrich, Milwaukee, WI, USA), dissolved in a $10 \%(\mathrm{v} / \mathrm{v})$ methanol/water solution. The relative uncertainty of the concentration of the $\mathrm{CH}_{3} \mathrm{Hg}$ standard used in this work was $4.1 \%(n=10)$ when calibrated by Cold Vapor Atomic Fluorescence Spectrophotometer against NIST SRM $3133^{28}$. Inorganic $\mathrm{Hg}(\mathrm{iHg})$ NIST SRM 3133 solution was used in this work. Diluted $\mathrm{CH}_{3} \mathrm{Hg}$ and $\mathrm{iHg}$ standard solutions were prepared in $0.5 \% \mathrm{w} / \mathrm{w}$ bidistilled $\mathrm{HCl}$ or $5 \mathrm{mMsodium}$ thiosulfate solution for the derivatization and halogenation experiments respectively. TORT-2 a freeze-dried lobster hepatopancreas tissue was obtained from the National Research Council Canada (NRCC). TORT-2 is characterized by a low certified $\mathrm{CH}_{3} \mathrm{Hg}$ concentration of $0.163 \pm 0.014 \mu \mathrm{g} \cdot \mathrm{g}^{-1}$ (as $\mathrm{CH}_{3} \mathrm{Hg}$ ), making it suitable to be used as a " $\mathrm{CH}_{3} \mathrm{Hg}$-blank" control matrix material to investigate the absence of matrix effect of the method. The second biological CRM used in this work was ERM-CE464, a tuna fish reference material representative of $322 \mathrm{Kg}$ of tuna collected in the Adriatic Sea. This material was obtained from the Institute for Reference Materials and Measurements (IRMM, Belgium). ERM-CE464 has an elevated certified $\mathrm{CH}_{3} \mathrm{Hg}$ concentration of $5.50 \pm 0.17 \mu \mathrm{g} \cdot \mathrm{g}^{-1}\left(\right.$ as $\left.\mathrm{CH}_{3} \mathrm{Hg}\right)$.

\section{GC-C-IRMS}

All $\delta^{13} \mathrm{C}_{\mathrm{CH} 3 \mathrm{Hg}}$ measurements were performed by $\mathrm{GC}$ C-IRMS (Thermo Scientific), consisting of a Trace GC Ultra coupled to Delta V Advantage IRMS with an Isolink GC coupling interface. Instrumental parameters (GC, combustion reactor and IRMS) are detailed in Table S1. A fused silica Agilent DB-5 column was used for the separation of propylated and ethylated $\mathrm{CH}_{3} \mathrm{Hg}$ and $\mathrm{iHg}$ compounds. A fused silica Restek RTX- 5 column with a lower film thickness was privileged in the case of halogenated $\mathrm{CH}_{3} \mathrm{Hg}$ compounds. Data illustrated in the text, figures and tables correspond to triplicate injections of each sample. Methylmercury $\delta^{13} \mathrm{C}$ values measured in this work are expressed relative to a high purity $\mathrm{CO}_{2}$ reference working gas (carbon dioxide N48, Messer France SAS, Puteaux, France), calibrated against reference materials USGS-24, IAEA-CH6, IAEA-600. ${ }^{13} \mathrm{C} /{ }^{12} \mathrm{C}$ ratios are normalized by the Vienna Pee Dee Belemnite (VPDB) reference standard and expressed in $\delta$ notation:

$$
\delta^{13} C(\% 0)=\left(\frac{\left(\frac{{ }^{13} C}{{ }^{12} C}\right)_{\text {sample }}}{\left(\frac{{ }^{13} C}{{ }^{12} C}\right)_{P D B}}-1\right) \times 1000
$$

\section{$\mathrm{CH}_{3} \mathrm{Hg}$ selective extraction method (SEM)}

The $\mathrm{CH}_{3} \mathrm{Hg}$ selective extraction method (SEM) used in this study correspond to an upscaled version of the original SEM, initially developed for $\mathrm{Hg} \mathrm{CSIA}^{28}$. Higher $\mathrm{CH}_{3} \mathrm{Hg}$ concentrations were required to reach the minimum amountsneeded for precise $\delta^{13} \mathrm{C}_{\mathrm{CH} 3 \mathrm{Hg}}$ measurements by GC-C-IRMS. Briefly, multiple (up to 4) $1 \mathrm{~g}$ aliquots of the same biological material were extracted separately during $1 \mathrm{~h}$ (420 rpm lengthwise agitation on a horizontal shaking table) in $50 \mathrm{ml}$ centrifuge tubes with $5 \mathrm{ml}$ of acidic sodium bromide $(30 \% \mathrm{w} / \mathrm{w}$ $\mathrm{NaBr}$ in 4 mol. $^{-1} \mathrm{H}_{2} \mathrm{SO}_{4}$ ), $10 \mathrm{ml}$ of aqueous cupric sulfate $\left(2.5 \% \mathrm{w} / \mathrm{w} \mathrm{CuSO}_{4}\right)$ and $10 \mathrm{ml}$ of toluene. The toluene fractions of each individual sample aliquot were then combined together. The $40 \mathrm{~mL}$ combined toluene fraction that contains $\mathrm{CH}_{3} \mathrm{HgBr}$ was then back-extracted with 4 $\mathrm{ml}$ of a $5 \mathrm{mM}$ sodium thiosulfate solution to get an aqueous and stable $\mathrm{CH}_{3} \mathrm{Hg}$-thiosulfate complex. Verification of the quantitative extraction and halogenation of $\mathrm{CH}_{3} \mathrm{Hg}$ and the absence of analytical degradation, while processing up to $4 \mathrm{~g}$ of biological material, was verified by Gas Chromatography Sector Field Inductively Coupled Plasma Mass Spectrometry (GC-SF-ICP-MS), before GC-C-IRMS analysis(See Table S2 for details)

\section{Derivatization vs. halogenation conditions}

The ethylation and propylation conditions used in this work follow the standard procedures used for $\mathrm{Hg}$ speciation by GC-ICP-MS ${ }^{34}$. Briefly, $\mathrm{CH}_{3} \mathrm{Hg}$ and $\mathrm{iHg}$ standards solutions were derivatized with $0.1 \mathrm{ml}$ of daily prepared $\mathrm{NaB}\left(\mathrm{C}_{2} \mathrm{H}_{5}\right)_{4}$ and $\mathrm{NaB}\left(\mathrm{C}_{3} \mathrm{H}_{7}\right)_{4}\left(20 \mathrm{mg} \cdot \mathrm{ml}^{-1}\right)$ in a $5 \mathrm{ml}$ acetate buffer solution $\left(0.1 \mathrm{~mol}^{. \mathrm{I}^{-1}}, \mathrm{pH}=3.9\right)$ and in the presence $0.5 \mathrm{ml}$ of hexane. Inorganic $\mathrm{Hg}$ concentration levels 
were spiked at the same $\mathrm{Hg}$ level as $\mathrm{CH}_{3} \mathrm{Hg}$. Samples were hand-shaken for $5 \mathrm{~min}$, before collecting the hexane phase, which was subsequently stored in GC vials at $-20^{\circ} \mathrm{C}$ before analysis. These operating conditions were found suitable to quantitatively derivatize all $\mathrm{Hg}$ compounds in the case of standard solutions at the concentration levels needed for GC-C-IRMS analysis (See FigureS1 for details).

The halogenation conditions used in this work are based on published operating protocols found elsewhere ${ }^{35,36}$ to form a volatile $\mathrm{CH}_{3} \mathrm{Hgl}$ compound.Briefly, $\mathrm{CH}_{3} \mathrm{Hgl}$ is produced by mixing the $\mathrm{CH}_{3} \mathrm{Hg}$ standard prepared in a $5 \mathrm{mM}$ sodium thiosulfate solution with $0.5 \mathrm{ml}$ of a 3 mol. I $^{-1}$ potassium iodide solution. The mixture is vortexed during $30 \mathrm{~s}$ and then kept in the dark during 10 min. The aqueous $\mathrm{CH}_{3} \mathrm{Hgl}$ compound is subsequently extracted into $10 \mathrm{~mL}$ of isooctane by vortexing the solution for 2 minutes. $\mathrm{CH}_{3} \mathrm{Hgl}$ standard solutions in isooctane were preconcentrated under a stream $\left(0.5 \mathrm{~L} \mathrm{~min}^{-1}\right)$ of nitrogen at room temperature. Given that $\mathrm{CH}_{3} \mathrm{Hg}$ thiosulfate complexes are also obtained at the end of the SEM, applying the halogenation method to form a $\mathrm{CH}_{3} \mathrm{Hgl}$ compound was found particularly suitable to determine precise $\delta^{13} \mathrm{C}_{\mathrm{CH} 3 \mathrm{Hg}}$ values for both the $\mathrm{CH}_{3} \mathrm{Hg}$ reference standard solution and for biological reference materials.

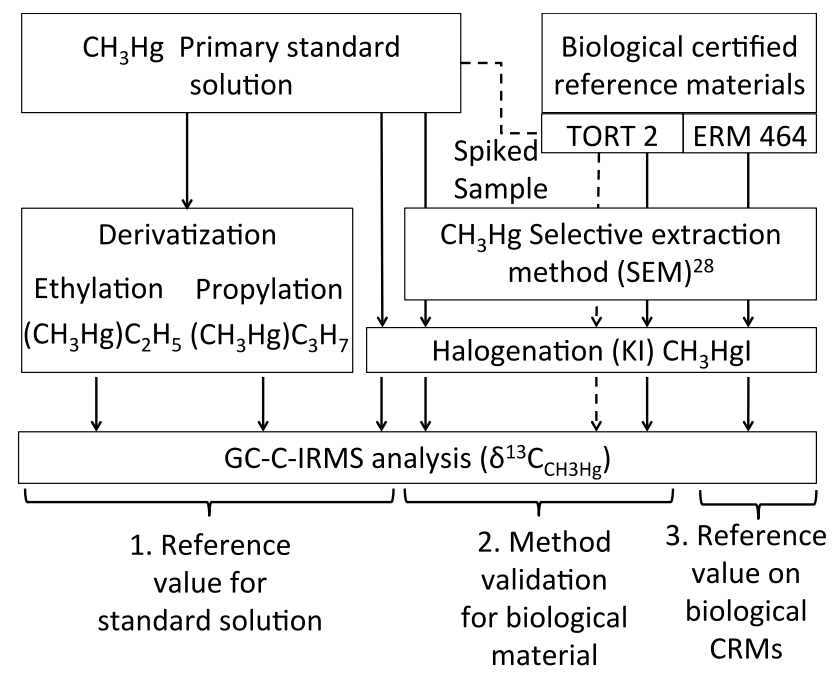

Figure 1. Operating procedure used for validating the analysis of $\delta^{13} \mathrm{C}_{\mathrm{CH} 3 \mathrm{Hg}}$ on natural biological samples.

\section{Safety considerations}

$\mathrm{Hg}$ compounds are toxic, and need to be handled only by experienced and well-trained personal, using all safety laboratory measures possible (gloves, glasses, fume hood).

\section{Results and Discussion}

Three consecutive steps were taken to develop the method for the determination of $\delta^{13} \mathrm{C}_{\mathrm{CH} 3 \mathrm{Hg}}$ values in reference standard solution and biological certified reference materials (Figure 1). This procedure consisted of:(i) Establishing reference $\delta^{13} \mathrm{C}$ values for a $\mathrm{CH}_{3} \mathrm{Hg}$ standard solution by comparing different independent derivatization and halogenation procedures; (ii) Validating the application of the selective extraction method ${ }^{28}$, by comparing ${ }^{13} \mathrm{C}_{\mathrm{CH} 3 \mathrm{Hg}}$ values of the primary $\mathrm{CH}_{3} \mathrm{Hg}$ standard solution processed with, without SEM, and with spiking the $\mathrm{CH}_{3} \mathrm{Hg}$ standard into a natural low $\mathrm{CH}_{3} \mathrm{Hg}$ reference material (TORT 2) to ensure the absence of matrix effects;(iii) Establishing a $\delta^{13} \mathrm{C}_{\mathrm{CH} 3 \mathrm{Hg}}$ preliminary reference valuefor a natural biological Tuna Fish reference material (ERM CE 464).

\section{Calibration of a $\mathrm{CH}_{3} \mathrm{Hg}$ standard for $\delta^{13} \mathrm{C}_{\mathrm{CH} 3 \mathrm{Hg}}$ analysis}

Derivatization (ethylation and propylation) vs. halogenation methods were compared for the same $\mathrm{CH}_{3} \mathrm{Hg}$ standard solution (Figure 1). The derivatization method represents an indirect approach for the determination of $\delta^{13} \mathrm{C}_{\mathrm{CH} 3 \mathrm{Hg}}$ values since the isotopic contribution of the exogenous carbon atoms present on the ethyl- and propyl- groups after $\mathrm{CH}_{3} \mathrm{Hg}$ derivatization $\left(\mathrm{CH}_{3} \mathrm{Hg}\left(\mathrm{C}_{2} \mathrm{H}_{5}\right)\right.$ in the case of ethylation and $\mathrm{CH}_{3} \mathrm{Hg}\left(\mathrm{C}_{3} \mathrm{H}_{7}\right)$ in the case of propylation) needs to be accounted and corrected for. By adding an inorganic $\mathrm{Hg}$ standard to the $\mathrm{CH}_{3} \mathrm{Hg}$ standard solution before derivatization, the resulting two derivatizediHg compounds in the case of ethylation are $\mathrm{CH}_{3} \mathrm{Hg}\left(\mathrm{C}_{2} \mathrm{H}_{5}\right)$ and $\mathrm{Hg}\left(\mathrm{C}_{2} \mathrm{H}_{5}\right)_{2}$ (Figure 2a), and $\mathrm{CH}_{3} \mathrm{Hg}\left(\mathrm{C}_{3} \mathrm{H}_{7}\right)$ and $\mathrm{Hg}\left(\mathrm{C}_{3} \mathrm{H}_{7}\right)_{2}$ in the case of propylation (Figure 2b).

The $\delta^{13} \mathrm{C}$ values of the exogenous carbon atoms of the ethyl and propyl groups can thus be determined on the $\mathrm{Hg}\left(\mathrm{C}_{2} \mathrm{H}_{5}\right)_{2}$ and $\mathrm{Hg}\left(\mathrm{C}_{3} \mathrm{H}_{7}\right)_{2}$ peaks. Subsequently a mass balance approach can be considered to estimate the endogenous $\delta^{13} \mathrm{C}$ values of $\mathrm{CH}_{3} \mathrm{Hg}$.

In the case of ethylation (Figure $2 \mathrm{a}$ ), $\delta^{13} \mathrm{C}_{\mathrm{CH} 3 \mathrm{Hg}}$ values can be estimated from the following equation:

$$
\delta^{13} C_{\mathrm{CH}_{3} \mathrm{Hg}}=3 \times \delta^{13} C_{\mathrm{CH}_{3} \mathrm{Hg}\left(\mathrm{C}_{2} \mathrm{H}_{5}\right)}-2 \times \delta^{13} C_{\mathrm{Hg}\left(\mathrm{C}_{2} \mathrm{H}_{5}\right)_{2}}
$$

In the case of propylation (Figure 2b), $\delta^{13} \mathrm{C}_{\mathrm{CH} 3 \mathrm{Hg}}$ values can be estimated from the following equation:

$$
\delta^{13} C_{\mathrm{CH}_{3} \mathrm{Hg}}=4 \times \delta^{13} C_{\mathrm{CH}_{3} \mathrm{Hg}\left(\mathrm{C}_{3} \mathrm{H}_{7}\right)}-3 \times \delta^{13} C_{\mathrm{Hg}\left(\mathrm{C}_{3} \mathrm{H}_{7}\right)_{2}}
$$

The halogenation method (Figure 2c) represents a direct approach for the determination of $\delta^{13} \mathrm{C}_{\mathrm{CH} 3 \mathrm{Hg}}$ values since no addition of exogenous carbon atoms is required. This approach consists of forming a volatile $\mathrm{CH}_{3} \mathrm{Hg}$-halide compound $\left(\mathrm{CH}_{3} \mathrm{Hgl}\right)$ that can be back-extracted into a solvent and analyzed directly by GC-C-IRMS. 

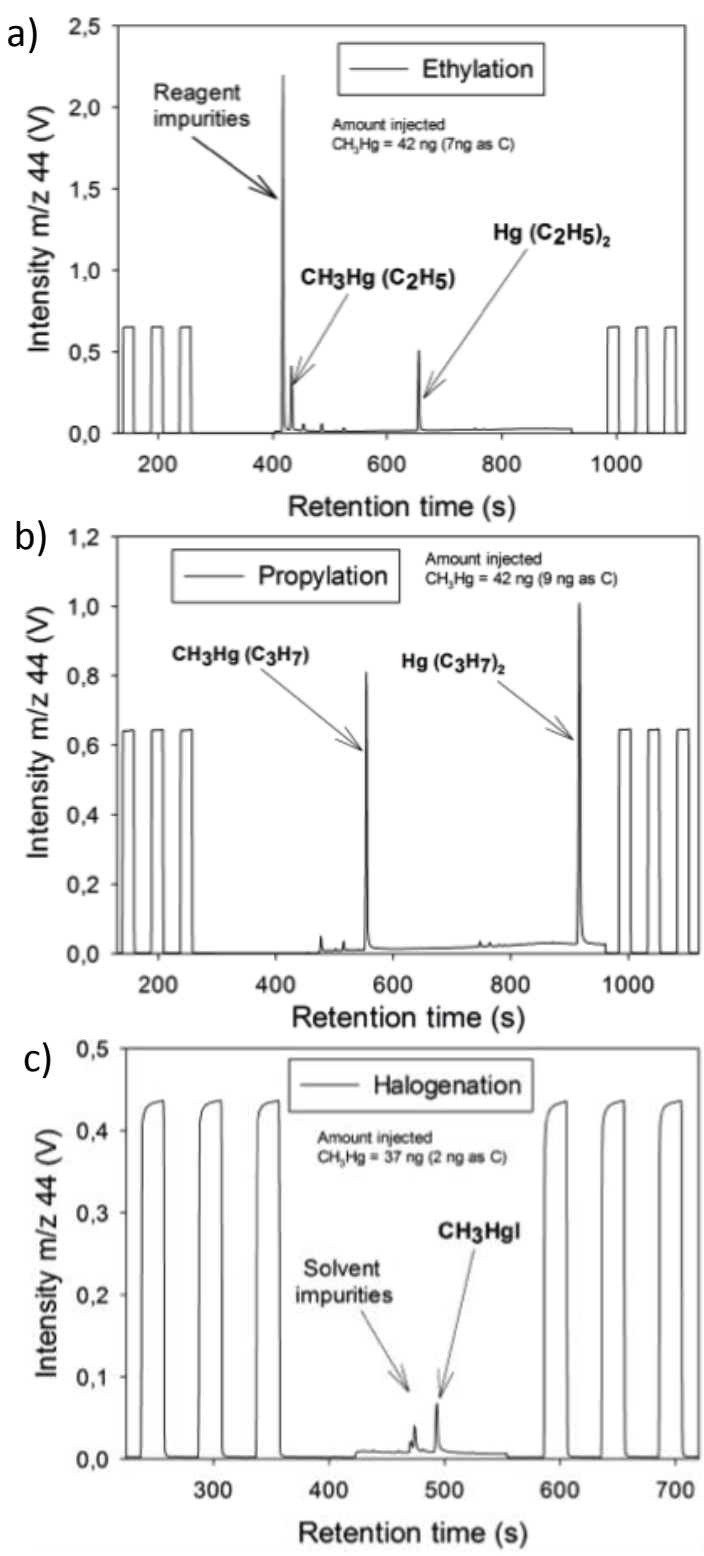

Figure 2. GC-C-IRMS chromatograms of alkylated and halogenated $\mathrm{CH}_{3} \mathrm{Hg}$ compounds.a) Ethylated $\mathrm{CH}_{3} \mathrm{Hg}$ $\left(\left(\mathrm{CH}_{3} \mathrm{Hg}\left(\mathrm{C}_{2} \mathrm{H}_{5}\right)\right)\right.$, b) Propylated $\mathrm{CH}_{3} \mathrm{Hg}\left(\left(\mathrm{CH}_{3} \mathrm{Hg}\left(\mathrm{C}_{3} \mathrm{H}_{7}\right)\right)\right.$, and (c) halogenated $\mathrm{CH}_{3} \mathrm{Hg} \quad\left(\mathrm{CH}_{3} \mathrm{Hgl}\right)$. Note that in the case of derivatized $\mathrm{CH}_{3} \mathrm{Hg}$ compounds, an $\mathrm{iHg}$ standardwas also spiked into the solution and co-derivatized with $\mathrm{CH}_{3} \mathrm{Hg}$ to allow for the correction of the carbon isotopic compositionof the respective ethyl and propyl groups attached to the $\mathrm{CH}_{3} \mathrm{Hg}$ molecule. Blank chromatograms of the ethylation, propylation and halogenation experiments are shown in Figure S1.

\section{Derivatization method}

The use of typical Sodium Tetraethylborate $\left(\mathrm{NaB}\left(\mathrm{C}_{2} \mathrm{H}_{5}\right)_{4}\right)$ and Sodium Tetrapropylborate $\left(\mathrm{NaB}\left(\mathrm{C}_{3} \mathrm{H}_{7}\right)_{4}\right)$ quantities as in Gas Chromatography Inductively Coupled Plasma Mass Spectrometry (GC-ICPMS) studies $\left(20 \mathrm{mg}^{\mathrm{mL}} \mathrm{m}^{-1}, 0.1 \mathrm{~mL}\right.$ ) was found sufficient to quantitatively derivatize about $21 \mu \mathrm{g}$ of $\mathrm{CH}_{3} \mathrm{Hg}(1.2 \mu \mathrm{g}$ as $\mathrm{C}$ ) and $20 \mu \mathrm{g}$ of $\mathrm{iHg}$ (back-extracted into $0.5 \mathrm{~mL}$ hexane) for precise determination of $\delta^{13} \mathrm{C}_{\mathrm{CH} 3 \mathrm{Hg}}$ values of the $\mathrm{CH}_{3} \mathrm{Hg}$ standard solution (see Figure $\mathrm{S} 2$ for details).

The analysis of the same $\mathrm{CH}_{3} \mathrm{Hg}$ standard solution derivatized over a wide rangeof ethylation and propylation reagent quantities lead to similar $\delta^{13} \mathrm{C}_{\mathrm{CH} 3 \mathrm{Hg}}$ values of $54.5 \pm 1.5 \%$ o ( $\pm 2 S D, n=6)$, and $-54.6 \pm 1.9 \%$ o $( \pm 2 S D, n=6)$ respectively (See Figure S2 for details). This results showed the absence of a significant effect of the amount and type of derivatization agent used on the determination of $\delta^{13} \mathrm{C}_{\mathrm{CH} 3 \mathrm{Hg}}$ values. A second derivatization of the remaining aqueous solutions did not reveal any residual peaks indicating the quantitative derivatization and backextraction of $\mathrm{CH}_{3} \mathrm{Hg}$ into hexane.

We subsequently used the referencederivatizationprotocol as determined above (20 mg. $\left.\mathrm{mL}^{-1}, 0.1 \mathrm{~mL}\right)$, and investigated $\delta^{13} \mathrm{C}_{\mathrm{CH} 3 \mathrm{Hg}}$ values over an analyte mass range of $5-80 \mu \mathrm{g}$ of $\mathrm{CH}_{3} \mathrm{Hg}(0.28-4.45 \mu \mathrm{g}$ as $\mathrm{C})$ while keeping the iHgconcentration constant $(20 \mu \mathrm{g}$, Figure $3 \mathrm{a}$ and $3 \mathrm{~b}$ ). This corresponds to a concentration range of 6$112 \mathrm{ng}$ of $\mathrm{CH}_{3} \mathrm{Hg}$ injected into the GCCIRMS, representing 1-19 ng and 1-25ngof carbon in the case of ethylation and propylation respectively. In terms of isotopic composition, homogenous $\delta^{13} \mathrm{C}_{\mathrm{CH} 3 \mathrm{Hg}}$ values were observed over theconcentration range considered. The highest precision and reproducibility of the measurements were obtained when $\mathrm{iHg} / \mathrm{CH}_{3} \mathrm{Hg}$ concentration ratios were in the range of 0.25 to 4 , and with a minimum peak intensity of approximately 0.3 Volts. Under these conditions, $\delta^{13} \mathrm{C}_{\mathrm{CH} 3 \mathrm{Hg}}$ measurements obtained for the same standard solution were found in good agreement using either ethylation $-55.1 \pm 0.9 \%$ ( $\pm 2 S D$, $n=5)$ and propylation $-54.9 \pm 1.7 \%$ o $( \pm 2 S D, n=5)$. These results indicate that in the case of quantitative derivatization yields and using $\mathrm{iHg}$ as an internal standard for correcting the isotopic contribution of the alkyl groups added to $\mathrm{CH}_{3} \mathrm{Hg}$ during the derivatization reaction, accurate, precise and reproducible $\delta^{13} \mathrm{C}_{\mathrm{CH} 3 \mathrm{Hg}}$ measurementscan be achieved.

\section{Halogenation method}

With only a single carbon atom present in $\mathrm{CH}_{3} \mathrm{Hgl}$, a significantly higher concentration of the $\mathrm{CH}_{3} \mathrm{Hg}$ standard was required to reach the sensitivity level required for precise measurements $\left(123 \mu \mathrm{g}\right.$ of $\mathrm{CH}_{3} \mathrm{Hg}$ in a $5 \mathrm{mM}$ sodium thiosulfate solution quantitatively back-extracted as $\mathrm{CH}_{3} \mathrm{Hgl}$ into $10 \mathrm{~mL}$ isooctane (see ${ }^{35}, 36$, and experimental section for details). The injection of this solution (37 $\mathrm{ng}$ of $\mathrm{CH}_{3} \mathrm{Hg} ; 2 \mathrm{ng}$ as $\mathrm{C}$ ) led to a $\delta^{13} \mathrm{C}_{\mathrm{CH}} \mathrm{Hg}$ value of $53.7 \pm 0.8 \%$ o ( $\pm 2 \mathrm{SD}, \mathrm{n}=3$ ).

The evaporation of the isooctane solution under $\mathrm{N}_{2}$ to different preconcentration levels analyzed by GC-CIRMS showed a linear relationship (Figure $3 c, R^{2}=0.99$ ) between $\mathrm{CH}_{3} \mathrm{Hgl}$ peak intensity and the corresponding amount of carbon injected. Identical $\delta^{13} \mathrm{C}_{\mathrm{CH} 3 \mathrm{Hg}}$ values were also measured for the different preconcentrated sub fractions (Figure $3 \mathrm{c}$ ). These results confirmed the absence of $\mathrm{CH}_{3} \mathrm{Hgl}$ loss and isotope fractionation artifact during the solvent preconcentration step. 

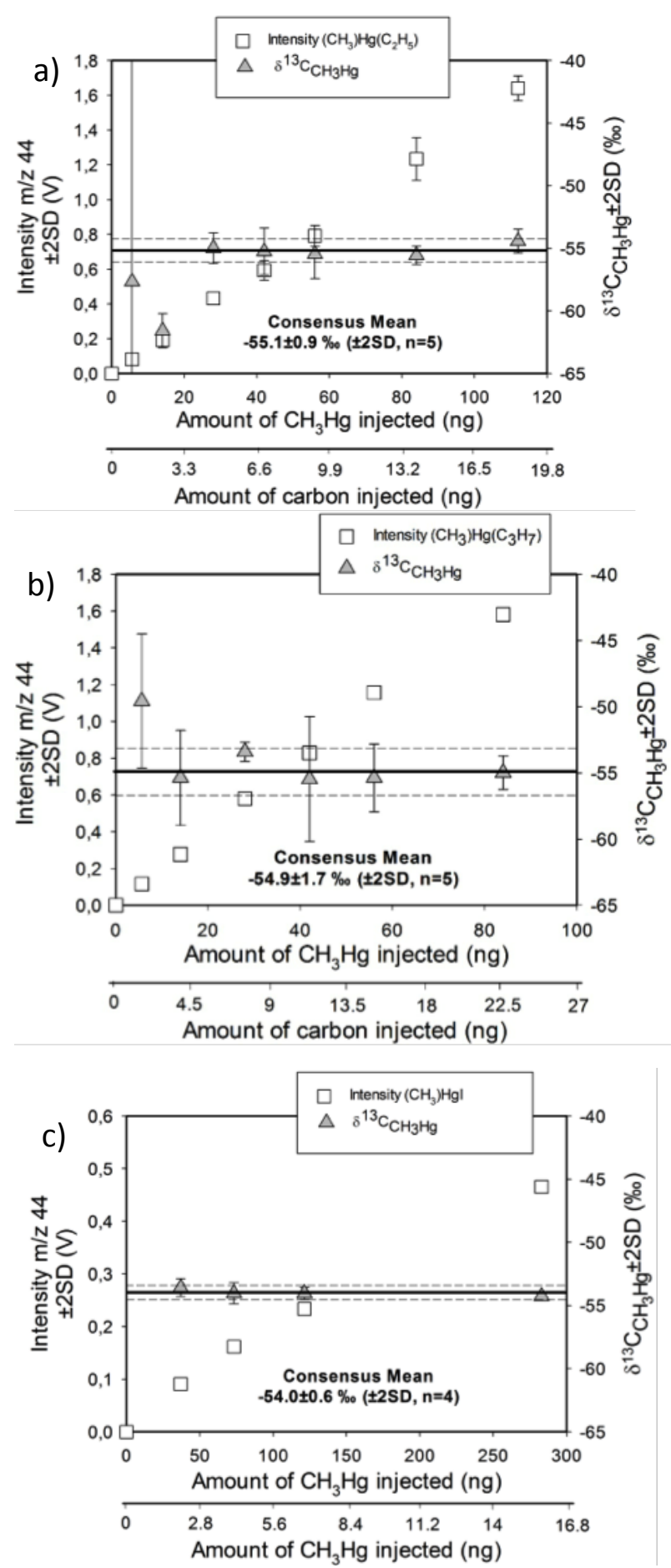

Figure 3. Influence of the concentration of $\mathrm{CH}_{3} \mathrm{Hg}$ on $\delta^{13} \mathrm{C}_{\mathrm{CH} 3 \mathrm{Hg}}$ values obtained after a) ethylation, b)propylationand c) halogenation of the same $\mathrm{CH}_{3} \mathrm{Hg}$ standard. Consensus mean values (plain line) and their uncertainty(dashed lines $( \pm 2 S D)$ ) are based on all measurements in the case of direct $\delta^{13} \mathrm{C}_{\mathrm{CH} 3 \mathrm{Hg}}$ determinations $\left(\mathrm{CH}_{3} \mathrm{Hgl}\right)$, and at peak intensities starting $0.3 \mathrm{~V}$ In the case of estimated $\delta^{13} \mathrm{C}_{\mathrm{CH} 3 \mathrm{Hg}}$ determinations by derivatization.
Further, a second halogenation step performed on the remaining aqueous phase after the initial halogenation of the $\mathrm{CH}_{3} \mathrm{Hg}$ standard solution did not reveal any residual $\mathrm{CH}_{3} \mathrm{Hgl}$ peak, also confirming the quantitative transfer of $\mathrm{CH}_{3} \mathrm{Hgl}$ into the organic phase prior to GC-C-IRMS analysis. The similar $\delta^{13} \mathrm{C}_{\mathrm{CH} 3 \mathrm{Hg}}$ values obtained over a $\mathrm{CH}_{3} \mathrm{Hgl}$ concentration range of 37 to $283 \mathrm{ng}$ of $\mathrm{CH}_{3} \mathrm{Hg}$ (2-16 $\mathrm{ng}$ as $\mathrm{C}$ ) led to a mean value of $-54.0 \pm 0.7 \%$ o $\left(( \pm 2 \mathrm{SD}, \mathrm{n}=4)\right.$, Fig 3c) for the $\mathrm{CH}_{3} \mathrm{Hg}$ reference standard.

In summary, the comparison of the $\delta^{13} \mathrm{C}_{\mathrm{CH} 3 \mathrm{Hg}}$ valuesobtained for the same $\mathrm{CH}_{3} \mathrm{Hg}$ standard solution showed similar valuesgiven uncertainties between indirect ethylation $(-55.1 \pm 0.9 \%$ o $( \pm 2 S D))$ and propylation ($54.9 \pm 1.7 \%$ o $( \pm 2 S D)$ ) approaches and the direct halogenation $(-54.0 \pm 0.7 \%$ o ( $\pm 2 S D))$ method. The precision of $\delta^{13} \mathrm{C}_{\mathrm{CH} 3 \mathrm{Hg}}$ values by the halogenation method appeared also to be significantly better relative to the propylation and ethylation methods. This difference is related to the larger uncertainty budgets of the indirect propylation and ethylation methods where carbon CSIA of two individual $\mathrm{Hg}$ compounds needs to be combined for estimating the endogenous composition of the carbon atom present in $\mathrm{CH}_{3} \mathrm{Hg}$. These results were also confirmed during a long-term reproducibility experiment (See TableS4for details). Given all uncertainties and the long-term ${ }^{13} \mathrm{C}_{\mathrm{CH} 3 \mathrm{Hg}}$ measurements obtained by the three independent methods, a $\delta^{13} \mathrm{C}_{\mathrm{CH} H \mathrm{Hg}}$ reference value of $53.8 \pm 1.1 \%$ ( $\pm 2 \mathrm{SD}$ ) was proposed for the $\mathrm{CH}_{3} \mathrm{Hg}$ standard solution used in this study.

\section{Method validation for $\delta^{13} \mathrm{C}_{\mathrm{CH} 3 \mathrm{Hg}}$ measurements on biological samples}

Accurate $\delta^{13} \mathrm{C}_{\mathrm{CH} 3 \mathrm{Hg}}$ measurements in biological samples require a quantitative extraction and purification of $\mathrm{CH}_{3} \mathrm{Hg}$ from the initial sample matrix to the intermediate sodium thiosulfate fraction, but also a quantitative transfer of $\mathrm{CH}_{3} \mathrm{Hg}$ from the sodium thiosulfate fraction to the final organic phase prior to GC-C-IRMS analysis.Complementary experiments conducted by GCSF-ICP-MS showed that the $\mathrm{CH}_{3} \mathrm{Hg}$ selective extraction method (SEM) we intially developped for $\mathrm{Hg} \mathrm{CSIA}^{28}$ was able to answer these needs (see Table S2 for details). While our standard SEM protocol ${ }^{28}$ was found to quantitatively extract and preconcentrate $\mathrm{CH}_{3} \mathrm{Hg}$ from several grams of biological material, preliminary attempts to derivatize the intermediate $\mathrm{CH}_{3} \mathrm{Hg}$-thosulfate complex were found unsuccessful. The strong $\mathrm{CH}_{3} \mathrm{Hg}$-S bond is known to inhibit the derivatizationprocess ${ }^{37}$, leading to low transfer yields towards the organic phase. On the contrary, the halogenation method hadpreviously been shown to successfully extract $\mathrm{CH}_{3} \mathrm{Hg}$ in the presence of sodium thiosulfate and to quantitatively form a $\mathrm{CH}_{3} \mathrm{Hgl}$ compound that can be back extracted into an organic solvent ${ }^{35}$. 
Table 1. Validationand application of the SEM for $\delta^{13} \mathrm{C}_{\mathrm{CH} 3 \mathrm{Hg}}$ measurements in biological materials.

\begin{tabular}{|c|c|c|c|c|c|c|}
\hline $\begin{array}{c}\text { Biological reference } \\
\text { material }^{*} \\
\text { (mass extracted } \\
(\mathrm{g}))\end{array}$ & $\begin{array}{l}\mathrm{CH}_{3} \mathrm{Hg} \text { spike } \\
\text { concentration }\end{array}$ & $\begin{array}{c}\text { SEM } \\
\text { replicates }^{* *} \\
(\mathrm{n})\end{array}$ & $\begin{array}{c}\mathrm{SEM} \mathrm{CH}_{3} \mathrm{Hg} \\
\text { recovery } \\
(\% \pm \mathrm{SD})^{\star * *}\end{array}$ & $\begin{array}{c}\text { Amount of } \\
\mathrm{CH}_{3} \mathrm{Hg} \text { injected } \\
\text { (ng), (ng. as C) }\end{array}$ & $\begin{array}{l}\text { Peak Intensi- } \\
\text { ty } \\
\mathrm{m} / \mathrm{z} 44(\mathrm{mV})\end{array}$ & $\begin{array}{c}\delta^{13} \mathrm{C}_{\mathrm{CH} 3 \mathrm{Hg}} \\
\pm 2 \mathrm{SD} \\
(\% 0)^{* * * *}\end{array}$ \\
\hline- & $20 \mu \mathrm{g}$ & 3 & $107 \pm 7$ & $306(17)$ & 488 & $-53.8 \pm 0.4$ \\
\hline TORT-2 $(0.4 \mathrm{~g})$ & $20 \mu \mathrm{g}$ & 1 & $108 \pm 5$ & $391(22)$ & 567 & $-54.2 \pm 0.4$ \\
\hline TORT-2 (3 g) & $20 \mu \mathrm{g}$ & 1 & $93 \pm 7$ & $378(21)$ & 527 & $-54.4 \pm 0.4$ \\
\hline ERM-CE464 (4g) & - & 4 & $103 \pm 6$ & $253(15)$ & 492 & $-22.1 \pm 1.5$ \\
\hline
\end{tabular}

* TORT-2: $0.163 \mu \mathrm{g} \cdot \mathrm{g}^{-1}$ (asCH $\mathrm{CH}_{3} \mathrm{Hg}$ ) certified concentration, ERM-CE464: $5.50 \mu \mathrm{g}^{-\mathrm{g}^{-1}}$ (asCH $\mathrm{CH}_{3} \mathrm{Hg}$ certified concentration

** Number of independent SEM replicates performed

*** Determined by external calibration based on a $\mathrm{CH}_{3} \mathrm{Hgl}$ standard calibration curve (non-processed by the SEM)

${ }^{* * * *}$ Average values and their uncertainties are based on the triplicate injection of each SEM replicate

The quantitative halogenation of $\mathrm{CH}_{3} \mathrm{Hg}$ in $5 \mathrm{mM}$ thiosulfate solution was also confirmed in this study by GC-SF-ICP-MS measurements (See Table S2 for details), performed on the same solvent fractions as those analyzed by GC-C-IRMS. For these reasons, the halogenation method has been chosento process the biological SEM extracts of $\mathrm{CH}_{3} \mathrm{Hg}$ in thiosulfate prior to ${ }^{13} \mathrm{C}_{\mathrm{CH} 3 \mathrm{Hg}}$ measurements by GC-C-IRMS.

We subsequently tested first the combined influence of the SEM and halogenation methods on the reference $\mathrm{CH}_{3} \mathrm{Hg}$ standard previously calibrated for $\delta^{13} \mathrm{C}_{\mathrm{CH} 3 \mathrm{Hg}}$ measurements. Results in Table 1 show that extracting $20 \mu \mathrm{g}$ of $\mathrm{CH}_{3} \mathrm{Hg}$ by the SEM, followed by halogenation and preconcentration of the isooctane phase resulted in a $\delta^{13} \mathrm{C}_{\mathrm{CH} H \mathrm{Hg}}$ value of $-53.8 \pm 0.4 \%$ $(( \pm 2 S D), n=3)$. This value is similar, given uncertainties with the reference value obtained for the same $\mathrm{CH}_{3} \mathrm{Hg}$ standard not processed by the SEM $(-53.8 \pm 1.1 \%$ ). $\mathrm{CH}_{3} \mathrm{Hg}$ standard recovery obtained after the SEM was $107 \pm 7 \%(n=3)$. This confirmed the quantitative extraction, purification, halogenation and preconcentrationof $\mathrm{CH}_{3} \mathrm{Hg}$ prior to GC-C-IRMS analysis. These results also indicated the absence of carbon isotope fractionation artifacts associated with the SEM when processing matrix-free $\mathrm{CH}_{3} \mathrm{Hg}$ standard solutions.

In a second step, we investigated the ability of the SEM-halogenation method to handle the same $\mathrm{CH}_{3} \mathrm{Hg}$ amount as processed above, but in the presence of a virtually "MeHg-blank" sample tissue matrix. Variable amounts $(0.4$ and $3 \mathrm{~g})$ of the NRCC-TORT-2 certified reference material, for which no $\mathrm{CH}_{3} \mathrm{Hg}$ peaks could be detected $(<15 \mathrm{mV})$ were spiked with $20 \mu \mathrm{g}$ of the previously $\delta^{13}$ Cisotopically characterized $\mathrm{CH}_{3} \mathrm{Hg}$ standard. As shown in Table 2, no matrix effects were observed to influence $\mathrm{CH}_{3} \mathrm{Hg}$ spike recovery (93$108 \%$ ) during the extraction, halogenation, and evaporation steps. The uncertainty budget of the $\mathrm{CH}_{3} \mathrm{Hg}$ recovery values reflects the combined influence of the uncertainty on the $\mathrm{CH}_{3} \mathrm{Hg}$ concentration in both the standard solution and the biological reference materials (See experimental section), but also theslight increase in $\mathrm{CH}_{3} \mathrm{Hg}$ signal due to the progressive evaporation of the few $\mu \mathrm{L}$ of $\mathrm{CH}_{3} \mathrm{Hgl}$ hexane solution occurring in the $\mathrm{GC}$ vial during the triplicate injection and analysis of each sample. This source of uncertainty could be eventually reduced by using a Programmed Temperature Vaporizing Injector (PTV) allowing to increase the sensitivity by injecting more sample and evaporating the hexane solution directly into the injector. However, and because of the absence of isotope fraction during the evaporation and preconcentration of $\mathrm{CH}_{3} \mathrm{Hgl}$ in the hexane phase (Figure 3c), this source of uncertainty has no influence on the precision and accuracy on the $\delta^{13} \mathrm{C}_{\mathrm{CH} 3 \mathrm{Hg}}$ measurements. Methylmercury $\delta^{13} \mathrm{C}$ analysis performed for the different tissue sample masses to $\mathrm{CH}_{3} \mathrm{Hg}$ spike concentrationratio conditions yield to similar ${ }^{13} \mathrm{C}$ values relative to the reference $\mathrm{CH}_{3} \mathrm{Hg}$ standard solution. This results confirmed the absence of isotope fractionation bias associated with the SEM when processing biological matrices for accurate $\delta^{13}$ Cmeasurements.

\section{$\delta^{13} \mathrm{C}_{\mathrm{CH} \text { Hg }}$ values for ERM-CE464 tuna fish materi- al}

The ERM-CE464 tuna fish freeze dried reference material was prepared in 1989 by the Institute for Reference Materials and Measurements (IRMM) from $322 \mathrm{Kg}$ of dorsal muscle orignating from several tuna fish individuals collected in the Adriatic basin of the Mediterranean Sea. ERM-CE464 is characterized by a high $\mathrm{CH}_{3} \mathrm{Hg}$ content $\left(5.50 \pm 0.17 \mu \mathrm{g} \cdot \mathrm{g}^{-1}\right.$ as $\left.\mathrm{CH}_{3} \mathrm{Hg}\right)$, and represents an ideal candidate material for applying the method developed in this study to establish a representative $\mathrm{CH}_{3} \mathrm{Hg} \quad \delta^{13} \mathrm{C}$ value. We prepared and analyzed $4 \mathrm{~g} \quad(\mathrm{n}=4)$ of ERM-CE464 (representing approximately $22 \mu \mathrm{g}$ of $\mathrm{CH}_{3} \mathrm{Hg}$ ), in the same way as the $\mathrm{CH}_{3} \mathrm{Hg}$ reference solution and TORT-2 spiking experiments (Table 2). Recovery of $\mathrm{CH}_{3} \mathrm{Hg}$ from ERM-CE464 was $103 \pm 6 \%$. A $\delta^{13} \mathrm{C}_{\mathrm{CH} 3 \mathrm{Hg}}$ value of $-22.1 \pm 1.5 \%$ ( $\left.\pm 2 \mathrm{SD}\right)$ was obtained for the $n=4$ independent SEMhalogenation extractions. 


\section{Conclusions}

In this work, we tested three techniques (propylation, ethylation, halogenation) to determine ${ }^{13} \mathrm{C} /{ }^{12} \mathrm{C}$ isotopic ratios of the carbon atom present in the methyl group of the $\mathrm{CH}_{3} \mathrm{Hg}$ compound in a commercial $\mathrm{CH}_{3} \mathrm{Hg}$ salt. A $\mathrm{CH}_{3} \mathrm{Hg} \delta^{13} \mathrm{C}$ reference value of $-53.8 \pm 1.1 \%$ ( $\left.\pm 2 \mathrm{SD}\right)$ was established for the commercial $\mathrm{CH}_{3} \mathrm{Hg}$ salt. The halogenation method was shown to yield the highest precision. Following our previously developed $\mathrm{CH}_{3} \mathrm{Hg}$ selective extraction method (SEM), we further show that the $\mathrm{CH}_{3} \mathrm{Hg}$ SEM is not only relevant for $\mathrm{Hg}-\mathrm{CSIA}^{28}$ but also now for C-CSIA of $\mathrm{CH}_{3} \mathrm{Hg}$ in biological samples. We found a $\delta^{13} \mathrm{C}_{\mathrm{CH} 3 \mathrm{Hg}}$ value of $-22.1 \pm 1.5 \%$ o $( \pm 2 S D)$ for the Adritic Sea tuna fish ERM-CE464 certified reference material. The tuna fish $\delta^{13} \mathrm{C}_{\mathrm{CH}} \mathrm{HH}$ value apperared closely related to Adriatic and Atlantic derived particulate organic matter $\delta^{13} \mathrm{C}_{\mathrm{POC}}$ of $-21 /$ $22 \%{ }^{38-41}$, but different from that of Terrestrial Organic Matter $(-27 /-28 \% 0)^{42}$ and from sediments of the Adriatic Sea ${ }^{38}$. Assuming that $\mathrm{CH}_{3} \mathrm{Hg} \delta^{13} \mathrm{C}$ fractionation is probably limited during $\mathrm{CH}_{3} \mathrm{Hg}$ biomagnification in marine food chains since $\mathrm{CH}_{3} \mathrm{Hg}$ is mostly preserved in fish tissues and efficiently transferred from one trophic level to the next, this would suggest that fresh marine algal organic matter is the most likely carbon source at the origin of bioaccumulated $\mathrm{CH}_{3} \mathrm{Hg}$ in tuna fish from this region.

We previously found $\mathrm{Hg}$-CSIA derived $\delta^{202} \mathrm{Hg}$ and $\Delta{ }^{199} \mathrm{Hg}$ compositions of $0.62 \pm 0.11 \%$ and $2.34 \pm 0.11 \%$ for ERM-CE464 ${ }^{28}$. These combined two dimensional (2D) $\mathrm{C}$ and $\mathrm{Hg}$ isotope compositions open up new opportunities to improve our knwoledge of the mercury cycle and to investigate the question of the origin of $\mathrm{CH}_{3} \mathrm{Hg}$ in marine ecosystems.

\section{ASSOCIATED CONTENT}

\section{Supporting Information}

The Supporting information file containsTable S1: GC-CIRMS instrumental conditions, Table S2: Quantitative extraction and halogenation efficiency of the SEM on natural biological material determined by GC-SF-ICP-MS, Table S3: GC-SF-ICP-MS instrumental conditions, Table S4: Summary of $\delta^{13} \mathrm{C}_{\text {Снзн }}$ values obtained for the $\mathrm{CH} 3 \mathrm{Hg}$ primary standard solution, comparing short term and long term measurements,Figure S1. GC-C-IRMS blank chromatograms, Figure S2: Influence of the amount and type of derivatizing agent in solution on the derivatization efficiency of $\mathrm{CH}_{3} \mathrm{Hg}$ and $\mathrm{iHg}$, and associated influence on $\delta^{13} \mathrm{C}_{\text {Снзн }}$ values. "This material is available free of charge via the Internet at http://pubs.acs.org."

\section{AUTHOR INFORMATION}

\section{Corresponding Author}

*david.point@ird.fr

\section{Author Contributions}

$\$$ These authors performed the measurements and supervised the method development. The manuscript was writ- ten through contributions of all authors. / All authors have given approval to the final version of the manuscript.

\section{ACKNOWLEDGMENT}

This work is supported by the CNRS MI « Instrumentation aux limites » Project 2D ORGANOMETAL grant and the Observatoire Midi Pyrénées (OMP) internal stable isotope funding to DP. JM is grateful to the "Ministére de l'EnseignementSupérieuret de la Recherche" for his Doctoral Fellowship (EcoleDoctorale ED SDU2E/UPS). A. Baya is thanked for technical assistance on the $\mathrm{CH}_{3} \mathrm{Hg}$ sample preparation and extraction.

\section{REFERENCES}

(1) Choi, A. L.; Grandjean, P. Environ. Chem.2008, 5, 112-120.

(2) Mason, R. P.; Reinfelder, J. R.; Morel, F. M. M. Water, Air, Soil Pollut.1995, 80, 915-921.

(3) Sunderland, E. M.; Mason, R. P. Global Biogeochem. Cycles2007, 21.

(4) Trasande, L.; Landrigan, P. J.; Schechter, C. Environ. Health Perspect.2005, 113, 590.

(5) Compeau, G.; Bartha, R. Appl. Environ. Microbiol.1985, 50, 498-502.

(6) Benoit, J. M.; Gilmour, C. C.; Mason, R. P. Appl. Environ. Microbiol.2001, 67, 51-58.

(7) Ranchou-Peyruse, M.; Monperrus, M.; Bridou, R.; Duran, R.; Amouroux, D.; Salvado, J. C.; Guyoneaud, R. Geomicrobiol. J. 2009, 26, 1-8.

(8) Parks, J. M.; Johs, A.; Podar, M.; Bridou, R.; Hurt, R. A.; Smith, S. D.; Tomanicek, S. J.; Qian, Y.; Brown, S. D.; Brandt, C. C.; Palumbo, A. V.; Smith, J. C.; Wall, J. D.; Elias, D. A.; Liang, L. Science2013, 339, 1332-1335.

(9) Celo, V.; Lean, D. R. S.; Scott, S. L. Sci. Total Environ.2006, 368, 126-137.

(10) Hintelmann, H. In Organometallics in Environment and Toxicology; The Royal Society of Chemistry, 2010, pp 365-401.

(11) Mason, R. P.; Reinfelder, J. R.; Morel, F. M. M. Environ. Sci. Technol.1996, 30, 1835-1845.

(12) Atwell, L.; Hobson, K. A.; Welch, H. E. Can. J. Fish. Aquat. Sci.1998, 55, 1114-1121.

(13) Watras, C. J.; Back, R. C.; Halvorsen, S.; Hudson, R. J. M.; Morrison, K. A.; Wente, S. P. Sci. Total Environ.1998, 219, 183-208.

(14) Olson, B. H.; Cooper, R. C. Nature1974, 252, 682683.

(15) Gilmour, C. C.; Henry, E. A.; Mitchell, R. Environ. Sci. Technol.1992, 26, 2281-2287.

(16) Merritt, K. A.; Amirbahman, A. Earth-Sci. Rev.2009, 96, 54-66.

(17) Mason, R. P. Trace Metals in Aquatic Systems; Wiley. com, 2013.

(18) Mason, R. P.; Fitzgerald, W. Deep Sea Res., Part I 1993, 40, 1897-1924.

(19) Sunderland; M., E.; Krabbenhoft; P., D.; Moreau; W., J.; Strode; A., S.; Landing; M., W. Global Biogeochem. Cycles2009, 23.

(20) Cossa, D.; Heimbürger, L.-E.; Lannuzel, D.; Rintoul, S. R.; Butler, E. C. V.; Bowie, A. R.; Averty, B.; Watson, R. J.; Remenyi, T. Geochim. Cosmochim. Acta2011, 75, 4037-4052.

(21) Heimbürger, L.-E.; Cossa, D.; Marty, J.-C.; Migon, C.; Averty, B.; Dufour, A.; Ras, J. Geochim. Cosmochim. Acta2010, 74, 5549-5559. 
(22) Bloom, N.; Fitzgerald, W. F. Anal. Chim. Acta 1988, 208, 151-161.

(23) Monperrus, M.; Tessier, E.; Amouroux, D.; Leynaert, A.; Huonnic, P.; Donard, O. Mar. Chem.2007, 107, 49-63.

(24) Hintelmann, H.; Evans, R. D.; Villeneuve, J. Y. J. Anal. At. Spectrom.1995, 10, 619-624.

(25) Blum, J. D.; Popp, B. N.; Drazen, J. C.; Anela Choy, C.; Johnson, M. W. Nat. Geosci.2013, 6, 879-884.

(26) Point, D.; Sonke, J. E.; Day, R. D.; Roseneau, D. G.; Hobson, K. A.; Vander Pol, S. S.; Moors, A. J.; Pugh, R. S.; Donard, O. F. X.; Becker, P. R. Nat. Geosci.2011, 4, 188-194.

(27) Epov, V. N.; Rodriguez-Gonzalez, P.; Sonke, J. E.; Tessier, E.; Amouroux, D.; Bourgoin, L. M.; Donard, O. F. X. Anal. Chem.2008, 80, 3530-3538.

(28) Masbou, J.; Point, D.; Sonke, J. E. J. Anal. At. Spectrom.2013.

(29) Larsen, T.; Ventura, M.; Andersen, N.; O’Brien, D. M.; Piatkowski, U.; McCarthy, M. D. Plos One2013, 8, e73441.

(30) Meier-Augenstein, W. Anal. Chim. Acta2002, 465, 6379.

(31) Merritt, D. A.; Hayes, J. M.; Marais, D. J. D. J. Geophys. Res.: Atmos.1995, 100, 1317-1326.

(32) Schmidt, T.; Zwank, L.; Elsner, M.; Berg, M.; Meckenstock, R.; Haderlein, S. Anal. Bioanal. Chem.2004, 378, 283-300.
(33) Wuerfel, O.; Diaz-Bone, R. A.; Stephan, M.; Jochmann, M. A. Anal. Chem.2009, 81, 4312-4319.

(34) Point, D.; Alonso, J. I. G.; Davis, W. C.; Christopher, S. J.; Guichard, A.; Donard, O. F.; Becker, P. R.; Turk, G. C.; Wise, S. A. J. Anal. At. Spectrom.2008, 23, 385-396.

(35) Uthe, J. F.; Solomon, J.; Grift, B. J. - Assoc. Off. Anal. Chem.1972, 55, 583-589.

(36) Wagemann; R.; Trebacz; E.; Hunt; R.; Boila; G. Environ. Toxicol. Chem.1997, 16, 1859-1866.

(37) Clarisse, O.; Hintelmann, H. J. Environ. Monit.2006, 8, $1242-1247$.

(38) Faganeli, J.; Pezdic, J.; Ogorelec, B.; Mišič, M.; Najdek, M. Cont. Shelf Res.1994, 14, 365-384.

(39) Tagliabue, A.; Bopp, L. Global Biogeochem. Cycles2008, 22.

(40) Hofmann, M.; Wolf-Gladrow, D. A.; Takahashi, T.; Sutherland, S. C.; Six, K. D.; Maier-Reimer, E. Mar. Chem. 2000, 72, 131-150.

(41) Fry, B.; Sherr, E. B. In Stable Isotopes in Ecological Research, Rundel, P. W.; Ehleringer, J. R.; Nagy, K. A., Eds.; Springer New York, 1989, pp 196-229.

(42) Fry, B. In Stable Isotope Ecology; Springer New York, 2006, pp 40-75.

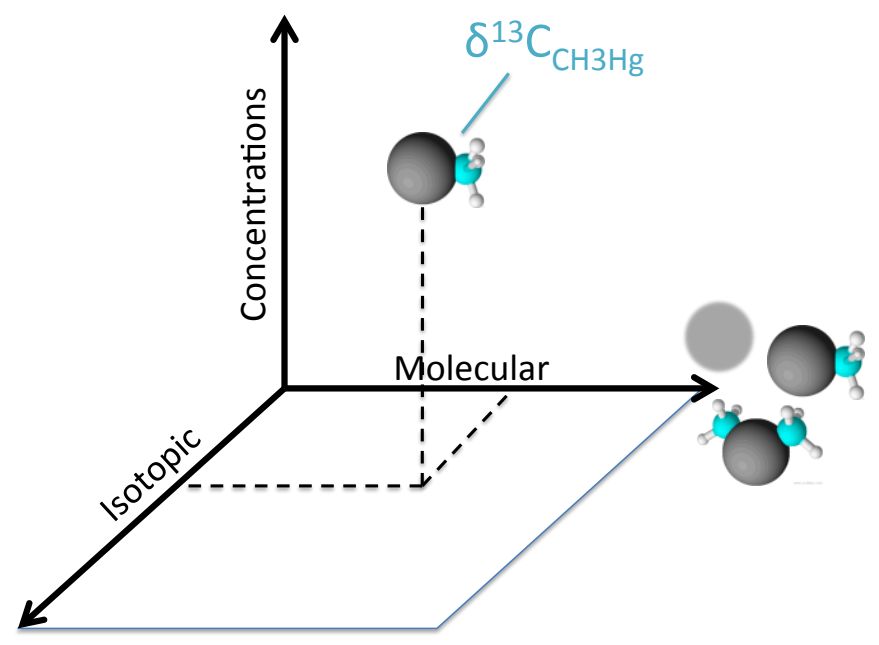

